\title{
Application of Immersive Method in the Teaching of Business English in Junior College
}

\author{
YANG Shuo \\ Jinlin Business and Technology College, ChangChun, 130507 \\ yangyu1983@sina.com
}

Key words: Immersive method; Business English; language environment

\begin{abstract}
Along with the rapid development of China's economy, as well as the trend of economic globalization, the market demands more talents who are specialized in business English. Nowadays, the daily English conversation and the specialized knowledge of business English are not closely combined in the teaching process. The Immersive method provides the learners with a favorable English context which preferably combines "business" and "English". Thus, it focuses on the acquisition of business knowledge, and has a special value and significance for the cultivation of business English talents.
\end{abstract}

\section{Introduction}

Along with the rapid development of China's economy, as well as the trend of economic globalization, the cultivation of interdisciplinary talents specialized in business English becomes an important sector in the English teaching in junior colleges. In this sector, the transition from "a person in education" to "a person in social activities" is the trend of cultivating new international-oriented talents. The new idea of discipline construction for cultivating business English talents with social orientation is to adjust the discourse type and to reconstitute the discipline's identity. Based on such idea, the business English courses in junior colleges must transform the paradigm of traditional teaching model for language skills, and convert the curriculum design into immersive teaching of knowledge related to business English, in order to establish a market-oriented interdisciplinary talent cultivation mode. Therefore, the application of immersive method in the teaching of business English in junior colleges is of special vale and significance for the cultivation of interdisciplinary specialized talents ${ }^{[1-6]}$.

\section{Immersive Method}

The immersive method, also known as the immersive bilingual educational method, is a teaching method which uses a non-mother and second language as the language of instruction. More specifically, the second language, as a tool of learning, is used for teaching and communicating not only in the class but also in the break time between classes. This method was first applied in the teaching of French language in Canada in the 1960s and achieved favorable effect. Canada is known to be a bilingual country where most people speak English and some people speak French. French speakers learn English easy because of the generally English-speaking environment, while the English speakers rarely contact and use French outside school where only some simple knowledge of French is taught. In 1965, in order for the English speakers to learn French better, the very first all-French teaching experiment was conducted at St. Lambert Elementary School in the suburb of Montreal, the teaching object being the kindergarten children whose mother language was English; and this experiment received wide attention from the society, parents and researchers. In a one-year period, the students who participated in this experiment were taught in French in at least half of all the courses including French course and other courses. With ultimately splendid teaching effect, the students not only mastered the basic French listening, speaking, reading and writing abilities, but also learned other fundamental courses by using French, by which they practiced their ability of thinking in French. Having developed in the past half century, Canada' s French-immersion teaching method has been recognized worldwide and referenced in the teaching of many other second languages.

Immersive method can be classified on the basis of time or of the proportion of use of second 
language. On the basis of time, the immersive method can be classified as early immersion, medium immersion and later immersion. The early immersion refers to the immersive learning in Preschool through Primary Three; the medium immersion refers to the immersive learning in Primary Four through Senior High; and the later immersion refers to the immersive learning in College. On the basis of the proportion of use of language, the immersive method can be classified as fully immersive bilingual learning and partly immersive English learning. The fully immersive English learning method completely uses second language as the language of instruction and activity, while the partly immersive English learning method keeps the proportion of the use of second language as the language of instruction and activity at $50 \%$.

\section{Immersive Method in the Teaching of Business English in Junior College}

The teaching of business English in the junior colleges of China has always been dominated by the training of language skills, with less attention paid on business-related professional knowledge. Thus, the graduates are only able for daily communications, but not familiar with specialized knowledge. This does not meet the demand of specialized market segmenting.

As the problem described in the above paragraph continues to exist in the teaching of business English in junior colleges, the way to perfectly combine English with specialized theoretical knowledge of business must be found. This requires that the curriculum design of business English course in junior college must base on business knowledge, but not on English language skill.

Teaching English with the immersive method can preferably solve the problem in the business English teaching in junior colleges, because the distinctive features of immersive English learning determines that the proportion of use of English in the teaching process is very high, which enables the learners to adapt to the learning and communication in an English language environment and thus to completely concentrate on the acquisition of business-related specialized theoretical knowledge. In this way, learners promote their English proficiency while acquiring the business-related specialized theoretical knowledge, and create a virtuous cycle of improvement both in daily English conversation and in the business-related specialized theoretical knowledge.

Immersive English teaching is a step-by-step teaching process, because the learner' s English proficiency must be considered. As English proficiency of Grade One students in junior college is generally lower than that of Grade Two, the business-related specialized knowledge in Grade One students' immersive English learning is basically English for business purposes. The language knowledge and skills in business English are acquired via common scenes and contexts of business. In this stage, the learning of language in business English is the top priority, while the specialized business knowledge plays the role as a carrier of context for language learning. In specific teaching process of business English, several topics involving specialized knowledge are chosen, and several key knowledge points are extended from these topics. The topics and key points are connected through fictitious scenes and contexts in such a way that a fairly integral field of business English is created in the classroom where the students immerge and strengthen their language awareness during conversations in daily English. Thus, the specialized knowledge of business English is invisibly transmitted to the Grade One students. For Grade Two students, since they already have some basic knowledge of spoken English, some certain professional subjects can be studied. In the study of professional subjects, the specialized knowledge related to marketing, international trade, finance and business laws and so on is taught on the basis of daily English conversations. In this way, the students are able to adapt to the learning and application of specialized knowledge of business English in the English language environment.

\section{Revelation of Immersive Method}

The practice of teaching business English in junior colleges indicates that the immersive English teaching in China' s junior colleges must carefully consider the following aspects:

First is curriculum design. Traditional teaching programs typically build on exam-oriented education, and the general English and the specialized business English are not organically combined. This results in a disconnection between the students' daily English conversations and 
their specialized knowledge. Therefore, the teaching program must be revised to ensure that both the general English including listening, speaking, reading and writing and the specialized business English are taught by means of the immersive method, using original English version of the textbook. In this way, the students' correctness of using specialized vocabulary and expressing specialized knowledge is guaranteed, and the students can understand and cognize the specialized knowledge through both eastern and western ways of thoughts, in line with international advanced technologies and ideas.

Second is development of teachers and corresponding teaching equipment. The teachers who teach English using immersive method must have a strong ability of expression in both English and Chinese. The teachers must not only be a language expert but also deeply understand the specialized business knowledge, knowing both western and eastern cultures well. But at present, business English teachers in China' $s$ junior colleges have some problems: some of them know the specialized knowledge well but not the English language knowledge, while some others are expert of English language knowledge but don' t know the business knowledge well. Therefore, the junior colleges must improve the teachers' comprehensive ability. It is shown in researches that training programs for college teachers can efficiently improve their ability. General English Course teachers and Business English Major Course teachers can complement each other. It would be very helpful for the development of English teachers if colleges could train these two groups of teachers together and let them communicate.

With the development in science and technology, the supplementary teaching means such as lantern slide, and teaching film and video have shown their limitations and deficiencies. Since the 1990s, with the development in computer technology, the multi-media teaching technology has shown its superiority. Because of its multiple functions such as the random access of information and the production of signal frame, and its creativity and convenience, it is popular among teachers and students. Compensating the deficiencies of listen-speak method, watch-listen method, situational method and communicative method in creating language environment, multi-media technology is a comparatively ideal supplementary teaching means. The sufficient development and exploitation of this technology will definitely take a positive and significant effect on English teaching. But currently, in most secondary technical schools, the equipment is insufficient in number, the audio lab equipment is outdated and hard to operate, and the multi-media classrooms are very few and cannot be normally utilized. These negatively affect the students' language acquisition to some extent. Therefore, the education administration authorities are expected to allocate special funds for supporting the improvement of hardware facilities and the construction of English cultural atmosphere in colleges.

Thirdly, for years, the learning of language knowledge has been put in the first place in the foreign language classroom teaching, and thus the teachers tend to dominate the classroom by telling and inculcating the knowledge. This model of teaching can only achieve the purpose of knowledge teaching, but can hardly train the students for their comprehensive English abilities, especially communicative ability. This model makes the students become used to passively receive information, and not form an individual thought or a unique opinion. The students only receive and store the knowledge output by the teacher, and won' $\mathrm{t}$ transform the knowledge into an ability, which results in "deaf English" and "dumb English". In order to change this situation, the measures of English teaching must be reformed. (1) The idea must be truly converted, and the passive situation in which teaching and learning are disconnected, so are learning and using, must be changed. English learners can keep permanent and deep learning interest, motivation and persistence by not only grasping some English language knowledge but also constantly improving the verbal ability required by the society. (2) Student must be centered, and the traditional teaching habit and model must be broken with. The teacher should be not only the imparter of knowledge but also the designer, organizer and participant of classroom communication activities. The teacher should be good at harmonizing the classroom atmosphere and arousing the students' language learning initiative through effective and interesting communicative activities. For example, while 
explaining the text, the teacher may arrange various classroom activities such as pair work, group discussion, class debate and speech based on the text' $s$ topic. These activities can activate the classroom atmosphere, wipe out the students' fatigue and improve their oral expression ability. The reformation of teaching model is not only the reform of teaching activities or means, but also the reform of teaching idea. The teacher-centered teaching model in which language knowledge and skills are simply imparted must be transformed into the student-centered model in which not only the language knowledge and skills are imparted but also the language using ability and initiative learning ability are developed. (3) The teaching should be individualized, with positive emotion factors considered and developed. The students' interest should be stimulated by various teaching forms and means. With the learners' enthusiasm of participation fully aroused, the output is maximized, and the learning effect guaranteed. (4) The training of learning strategies should be conducted, by which the students' initiative learning ability is developed, in order for them to independently determine their learning purposes, goals, contents and methods, as well as their own evaluation systems. (5) While the classroom teaching is attached great importance to, the students should also be guided for after-class study.

Fourth is immersion environment. Since a huge cultural gap lies between the eastern and the western world, not to mention China as a non-English country, the students in junior colleges are hardly able to think in English. Therefore, the challenge of creating an English language environment lies ahead of every junior college. To maintain an English language environment, the students must be inspired to be interested in English; once they are interested, they' ll communicate in English; once they communicate more, they' ll transform their way of thinking, and then, English becomes a means of communication among teachers and students.

\section{Conclusion}

Business English is a discipline of strong applicability and practicability, and because of its professionalism and interdisciplinarity, immersive method is very applicable to the teaching of business English. Immersive method provides students major in business English with a favorable language environment where they listen, speak, read and write using the target language, in such a way that they improve both language skills and specialized knowledge. Although immersive method is just started out in China, the teaching of English will definitely develop steadily in China with the effort of the educators.

\section{References}

[1] Yu Xi.Study on Immersion Foreign Language Teaching and Its Practice in China.Chong qing: Southwest University.(2009)

[2] Zhang Lulu.Review on Immersive Grammar Teaching.Education Frontier.Vol.06(2015).p.297

[3] Lu Xuanxuan.Enlightenment of Immersion Teaching on College English Teaching Reform.GVANGJSIHGYAUYUZ.Vol.03(2015).p.135-136

[4] Zhang Zhu.Canadian French Immersion Education and Its Inspirations for Bilingual Teaching in China’s Universities and Colleges.Tianjin:Tianjin University of Technology.(2010)

[5] Yuan Pinghua.Immersion Education of Bilingual Teaching of the University of Ottawa in Canada and Its Inspiration for English Teaching in China's Universities.Foreign Language Word.Vol.04(2011).p.75-82

[6] Yue Feng.Inspiration of American Immersion Teaching for English Teaching in China.Journal of Changchun Education Institute.Vol.31(2015).p.97-98 